\title{
A Common P2 Promoter Polymorphism of the Hepatocyte Nuclear Factor- $4 \alpha$ Gene Is Associated with Insulin Secretion in Non-Obese Japanese with Type 2 Diabetes
}

\author{
AYUMI TOKUNAGA, YUKIO HORIKAWA*, ETSUKO FUKUDA-AKITA, KOHEI OKITA, \\ HIROMI IWAHASHI, IICHIRO SHIMOMURA, JUN TAKEDA* AND KAZUYA YAMAGATA** \\ Department of Metabolic Medicine, Graduate School of Medicine, Osaka University, Osaka, Japan \\ *Department of Diabetes and Endocrinology, Gifu University School of Medicine, Gifu, Japan \\ **Department of Medical Biochemistry, Faculty of Medical and Pharmaceutical Sciences, Kumamoto University, Kumamoto, Japan
}

\begin{abstract}
Aims. Heterozygous mutations of the hepatocyte nuclear factor (HNF)- $4 \alpha$ gene cause a particular form of maturity-onset diabetes of the young (MODY1). Recent genetic studies have shown that single nucleotide polymorphisms (SNPs) of the $\beta$-cell type P2 promoter of the HNF-4 $\alpha$ gene are associated with type 2 diabetes in some populations. In the Japanese population, a haplotype consisting of two SNPs (rs1884614 and rs2144908) in the P2 promoter region is reported to show a significant association with type 2 diabetes. Methods. Both rs 1884614 and rs2144908 were genotyped in 349 type 2 diabetic patients and 203 non-diabetic controls. The relation of these SNPs to clinical characteristics was also examined in the diabetic subjects. Results. There were no differences in the genotype distribution of the two SNPs between the control and diabetic subjects, and the haplotype distribution was also similar in the two groups. However, the rs $1884614 \mathrm{~T} / \mathrm{T}$ genotype was significantly associated with a smaller area under the plasma insulin curve (AUC) during the OGTT in non-obese $\left(\mathrm{BMI}<25 \mathrm{~kg} / \mathrm{m}^{2}\right)$ patients $(\mathrm{p}=0.0272$; adjusted for age and sex). Conclusions. SNP rs 1884614 in the P2 promoter region of the HNF- $4 \alpha$ gene may influence insulin secretion in non-obese Japanese subjects with type 2 diabetes.
\end{abstract}

Key words: HNF-4a, Single nucleotide polymorphism, Type 2 diabetes, Insulin

(Endocrine Journal 55: 999-1004, 2008)

HEPATOCYTE nuclear factor (HNF)- $4 \alpha$, a transcription factor belonging to the nuclear hormone receptor superfamily (NR2A1), is expressed in the liver, kidneys, intestine, and pancreas $[1,2]$. Maturity-onset diabetes of the young (MODY) is a genetically heterogenous monogenic disorder that accounts for 2 to $5 \%$ of type 2 diabetes. It is characterized by autosomal dominant inheritance and an early age of onset (usually $<25$ years old). We have previously shown that heterozygous mutations of the HNF- $4 \alpha$ gene cause a

Received: March 15, 2008

Accepted: July 3, 2008

Correspondence to: Kazuya YAMAGATA, M.D., Ph.D., Department of Medical Biochemistry, Faculty of Medical and Pharmaceutical Sciences, Kumamoto University, 1-1-1 Honjo, Kumamoto 860-8556, Japan particular form of MODY (MODY1) [3]. Clinical studies have indicated that the primary cause of MODY1 is impairment of acute insulin secretion by pancreatic $\beta$-cells in response to a glucose load $[4,5]$, indicating that loss of HNF- $4 \alpha$ leads to abnormal insulin secretion by these cells. Targeted disruption of HNF- $4 \alpha$ in mouse pancreatic $\beta$-cells has revealed that HNF- $4 \alpha$ controls insulin secretion, at least partly, by regulating $\mathrm{K}_{\mathrm{ATP}}$ channel function [6,7].

Interestingly, recent genetic studies have shown that single nucleotide polymorphisms (SNPs) of the $\beta$-cell type $\mathrm{P} 2$ promoter (located about $46 \mathrm{~kb}$ upstream of the original liver type P1 promoter) of the HNF- $4 \alpha$ gene are associated with type 2 diabetes in some populations [8-13]. These findings indicate that HNF-4 $\alpha$ mutations do not only cause MODY, and that variations of the HNF- $4 \alpha$ gene may also be associated with 
Table 1. Clinical characteristics of the study subjects

\begin{tabular}{lccc}
\hline & Type 2 diabetic subjects & nondiabetic subjects & $\mathrm{p}$ \\
\hline $\mathrm{n}$ & 349 & 203 & \\
Age $($ years $)$ & $62.3 \pm 0.6$ & $67.7 \pm 0.7$ & $<0.001$ \\
$\mathrm{Sex}(\mathrm{M} / \mathrm{F})$ & $190 / 159$ & $94 / 109$ & N.S. \\
$\mathrm{BMI}\left(\mathrm{kg} / \mathrm{m}^{2}\right)$ & $24.2 \pm 0.3$ & $23.0 \pm 0.3(201)$ & 0.006 \\
$\mathrm{FPG}(\mathrm{mg} / \mathrm{dl})$ & $162.9 \pm 3.1$ & $92.8 \pm 0.5$ & $<0.001$ \\
$\mathrm{HbA}$ & $(\%)$ & $4.9 \pm 0.0(171)$ & $<0.001$ \\
$\mathrm{~F}-\mathrm{IRI}(\mu \mathrm{U} / \mathrm{ml})$ & $10.5 \pm 0.1$ & $6.2 \pm 0.2(167)$ & $<0.001$ \\
$\mathrm{HOMA}-\mathrm{IR}$ & $2.4 \pm 0.1(152)$ & $1.4 \pm 0.0(167)$ & $<0.001$ \\
\hline
\end{tabular}

Data are $\mathrm{n}$ or mean \pm SEM. HOMA-IR $=\mathrm{FPG}(\mathrm{mg} / \mathrm{dl}) \times \mathrm{F}-\mathrm{IRI}(\mu \mathrm{U} / \mathrm{ml}) / 405$.

Numbers of available data are shown in each parenthesis. The clinical characteristics of diabetic patients are those recorded at the time of hospitalization.

a predisposition to common type 2 diabetes. In the Japanese population, it has been reported that a haplotype consisting of two SNPs (rs1884614 and rs 2144908 ) in the $\mathrm{P} 2$ promoter region is significantly associated with type 2 diabetes [14]. In contrast, another study failed to detect any risk associated with this haplotype in the same population [15]. In the present study, we examined the contribution of these two SNPs to the susceptibility of Japanese to type 2 diabetes and their influence on quantitative parameters of insulin secretion.

\section{Subjects and Methods}

\section{Subjects}

We enrolled 349 unrelated Japanese subjects with type 2 diabetes who had been admitted to Osaka University Hospital and 203 unrelated Japanese nondiabetic control subjects. The clinical characteristics of the subjects are shown in Table 1. Type 2 diabetes was diagnosed in accordance with the World Health Organization criteria. In all patients, type 2 diabetes was first detected after the age of 40 years. Patients with type 1 diabetes or other types of diabetes (such as maturity onset diabetes of the young) were excluded from the study. This study was approved by the ethics committee of Osaka University and written informed consent was obtained from each participant.

\section{Biological measurements}

Chronic hyperglycemia is one of the factors that has a detrimental effect on early-phase insulin secretion (glucotoxicity) [16-18], and this impaired insulin response due to glucotoxicity is partly reversible after treatment of hyperglycemia. After hospitalization, the diabetic patients were treated by diet alone, or regular/ ultrarapid insulin before each meal, for at least 2 weeks. At the time when FPG was below $126 \mathrm{mg} / \mathrm{dl}$ as a result of treatment, a 75-g OGTT was performed in 109 subjects after an overnight fast, as described previously [19]. Blood samples were collected at 0 , 30,60 , and 120 minutes. The insulinogenic index was defined as the ratio of the increment of insulin to that of plasma glucose at 30 minutes after the glucose load ( $\Delta$ insulin $0-30$ minutes/ $\Delta \mathrm{PG} 0-30$ minutes), and was calculated to assess early-phase insulin secretion [20]. Homeostasis model assessment of insulin resistance (HOMA-IR) was used to estimate insulin sensitivity, which was calculated as follows: [fasting plasma glucose $(\mathrm{mg} / \mathrm{dl})] \times[$ fasting IRI $(\mu \mathrm{U} / \mathrm{ml})] / 405$. In addition, a glucagon stimulation test was performed by infusing $1 \mathrm{mg}$ of glucagon (Novo Nordisk Pharma. Ltd., Tokyo, Japan) intravenously after an overnight fast. Blood samples were collected at 0 and 5 minutes.

\section{Genotyping of HNF-4a polymorphisms}

Genotyping of two single nucleotide polymorphisms (rs1884614 and rs2144908) of HNF-4 $\alpha$ was performed by using the TaqMan SNP Genotyping Assays (Applied Biosystems, Foster City, CA). The PCR primers and oligonucleotide probes were purchased from Applied Biosystems. The PCR parameters were 2 min at $50^{\circ} \mathrm{C}, 10 \mathrm{~min}$ at $95^{\circ} \mathrm{C}$, and 40 cycles of $15 \mathrm{~s}$ at $95^{\circ} \mathrm{C}$ and $60 \mathrm{~s}$ at $60^{\circ} \mathrm{C}$. Then the alleles of the PCR products were determined with an ABI PRISM 7900 HT Sequence Detection System (Applied Biosystems). 
Table 2. Comparison of genotypic and allelic distribution of the SNPs between type 2 diabetic and nondiabetic subjects

\begin{tabular}{|c|c|c|c|c|c|c|c|}
\hline Polymorphisms & \multicolumn{2}{|c|}{ Allele frequency (\%) } & $\mathrm{p}$ & \multicolumn{3}{|c|}{ Genotype distribution (\%) } & $\mathrm{p}$ \\
\hline rs 1884614 & $\mathrm{C}$ & $\mathrm{T}$ & & $\mathrm{C} / \mathrm{C}$ & $\mathrm{C} / \mathrm{T}$ & $\mathrm{T} / \mathrm{T}$ & \\
\hline T2DM $(\mathrm{n}=349)$ & 55.0 & 45.0 & & 29.5 & 51.0 & 19.5 & \\
\hline $\operatorname{NDM}(n=203)$ & 53.4 & 46.6 & 0.614 & 30.5 & 45.8 & 23.6 & 0.405 \\
\hline rs2144908 & G & A & & $\mathrm{G} / \mathrm{G}$ & $\mathrm{G} / \mathrm{A}$ & $\mathrm{A} / \mathrm{A}$ & \\
\hline T2DM $(\mathrm{n}=349)$ & 54.6 & 45.4 & & 28.9 & 51.3 & 19.8 & \\
\hline $\operatorname{NDM}(\mathrm{n}=203)$ & 52.2 & 47.8 & 0.447 & 29.1 & 46.3 & 24.6 & 0.359 \\
\hline
\end{tabular}

T2DM: type 2 diabetic subjects. NDM: nondiabetic subjects.

When these two SNPs were sequenced in 20 randomly selected subjects, the results were compatible with the genotyping data obtained by using the TaqMan assay.

\section{Statistical analysis}

Results are shown as the mean \pm SE. Data on the insulinogenic index were logarithmically transformed to approximate a normal distribution. The HardyWeinberg equilibrium was assessed by $\chi^{2}$ analysis. Linkage disequilibrium (LD) and haplotype analyses were performed with SNPAlyze version 5.1 software (Dynacom, Japan). The frequencies of alleles or genotypes were compared by the $\chi^{2}$ test. Differences of continuous variables among genotypes were evaluated by one-way ANOVA. All statistical analyses were performed with StatView Ver. 5.0 software (SAS Institute Inc., Cary, NC), and statistical significance was defined as $P<0.05$.

\section{Results}

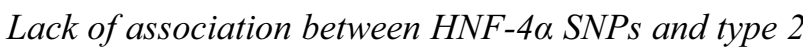 diabetes}

We genotyped two SNPs (rs1884614 and rs2144908) of HNF-4 $\alpha$ in Japanese subjects (Table 2). The frequency of each genotype of these two SNPs was in accord with the Hardy-Weinberg equilibrium $(P=0.53$ in controls and $P=0.90$ in diabetic patients for rs 1884614, $P=0.59$ in controls and $P=0.87$ in diabetic patients for rs2144908). There were no differences in the genotype distribution of rs 1884614 between control and diabetic subjects, and the genotype distribution of rs 2144908 was also similar in the
Table 3. Haplotype frequencies of rs 1884614 and rs 2144908 between type 2 diabetic and nondiabetic subjects

\begin{tabular}{cccccccc}
\hline \multirow{2}{*}{ Haplotype } & & \multicolumn{2}{c}{$\begin{array}{c}\text { Frequency } \\
\text { (this study) }\end{array}$} & & \multicolumn{2}{c}{$\begin{array}{c}\text { Frequency } \\
\text { (Takeuchi } \text { et al. })\end{array}$} \\
\cline { 1 - 1 } \cline { 6 - 8 } rs1884614 & rs2144908 & & T2DM & NDM & & T2DM & NDM \\
\hline C & G & & 0.544 & 0.522 & & 0.548 & 0.572 \\
$\mathrm{~T}$ & $\mathrm{~A}$ & & 0.451 & 0.466 & & 0.450 & 0.426 \\
$\mathrm{C}$ & $\mathrm{A}$ & & 0.004 & 0.012 & & 0.002 & 0.002 \\
$\mathrm{~T}$ & $\mathrm{G}$ & & - & - & & - & - \\
\hline
\end{tabular}

T2DM: type 2 diabetic subjects. NDM: nondiabetic subjects.

two groups. The two SNPs showed strong linkage disequilibrium $\left(r^{2}=0.98\right.$ in diabetic subjects and $r^{2}=$ 0.95 in control subjects). A minor haplotype (TG for rs1884614 and rs2144908) has been reported to show an association with type 2 diabetes in the Japanese population [14]. However, the existence of this haplotype was not estimated in either our control or diabetic subjects in the present study (Table 3), in accordance with the report of Takeuchi et al. [15]. The frequencies of the haplotypes detected were similar in the control and diabetic groups.

\section{Association between rs 1884614 and AUC-insulin}

To examine the effect of the two SNPs on clinical parameters, 75 g-OGTT was performed in 109 diabetic subjects after minimization of any potential influence of glucotoxity. Since rs1884614 and rs2144908 showed strong linkage disequilibrium, we only examined the influence of rs1884614 in these assessments. No differences were observed with respect to the fasting plasma glucose, $\mathrm{HbA}_{1 c}$, $\mathrm{BMI}$, diabetic duration, treatment of diabetes, fasting insulin, homeostasis model assessment of insulin resistance (HOMA-IR), 
Table 4. Clinical characteristics of obese/non-obese Type 2 diabetic subjects in whom 75 g-OGTT was performed

\begin{tabular}{lcccc}
\hline & total & obese subjects & non-obese subjects & $\begin{array}{c}\text { p } \\
\text { (obese vs. non-obese) }\end{array}$ \\
\hline $\mathrm{n}$ & 109 & 54 & 55 & \\
Age (years) & $61.5 \pm 0.9$ & $58.9 \pm 1.2$ & $64.0 \pm 1.2$ & 0.005 \\
Sex $(\mathrm{M} / \mathrm{F})$ & $51 / 58$ & $22 / 32$ & $29 / 26$ & N.S. \\
BMI $\left(\mathrm{kg} / \mathrm{m}^{2}\right)$ & $25.1 \pm 0.5$ & $28.7 \pm 0.7$ & $21.6 \pm 0.3$ & $<0.001$ \\
Duration (years) & $12.2 \pm 0.8$ & $10.6 \pm 1.0$ & $13.7 \pm 1.3$ & N.S. \\
Treatment (Diet/OHA/Insulin) & $17 / 68 / 24$ & $9 / 33 / 12$ & $8 / 35 / 12$ & N.S. \\
Family History $(+/-)$ & $57 / 52$ & $31 / 24$ & $26 / 28$ & N.S. \\
FPG $(\mathrm{mg} /$ dl) & $115.8 \pm 1.7$ & $113.4 \pm 2.2$ & $118.1 \pm 2.5$ & N.S. \\
HbA $(\%)$ & $9.1 \pm 0.2$ & $9.2 \pm 0.2$ & $9.0 \pm 0.3$ & N.S. \\
F-IRI $(\mu \mathrm{H} / \mathrm{ml})$ & $7.4 \pm 0.5$ & $9.3 \pm 0.8$ & $5.6 \pm 0.5$ & $<0.001$ \\
HOMA-IR & $2.1 \pm 0.2$ & $2.6 \pm 0.2$ & $1.6 \pm 0.2$ & 0.001 \\
I.I. & $0.18 \pm 0.02$ & $0.22 \pm 0.02$ & $0.13 \pm 0.02$ & N.S. \\
u-CPR $(\mu \mathrm{g} /$ day) & $65.9 \pm 4.1(100)$ & $68.8 \pm 6.2(50)$ & $63.0 \pm 5.5(50)$ & $<0.001$ \\
$\Delta$ CPR & $2.3 \pm 0.1(105)$ & $2.8 \pm 0.2(53)$ & $1.9 \pm 0.2(52)$ & $<0.001$ \\
AUC-insulin & $63.8 \pm 5.1$ & $81.6 \pm 8.6$ & $46.3 \pm 4.8$ & \\
\hline
\end{tabular}

Data are $\mathrm{n}$ or mean \pm SEM. HOMA-IR $=$ FPG $(\mathrm{mg} / \mathrm{dl}) \times$ F-IRI $(\mu \mathrm{U} / \mathrm{ml}) / 405$.

Obese: BMI $\geq 25 \mathrm{~kg} / \mathrm{m}^{2}$, non-obese: BMI $<25 \mathrm{~kg} / \mathrm{m}^{2}$, I.I.: insulinogenic index. AUC: area under the curve. Family History: presence of type 2 diabetes among their third-degree relatives. Data of FPG, F-IRI, and HOMA-IR at the time of 75 g-OGTT are shown. Numbers of available data are shown in each parenthesis.

Table 5. Genotypes of rs 1884614 and clinical data of non-obese (BMI $<25 \mathrm{~kg} / \mathrm{m}^{2}$ ) diabetic subjects

\begin{tabular}{lccccc}
\hline & $\mathrm{C} / \mathrm{C}$ & $\mathrm{C} / \mathrm{T}$ & $\mathrm{T} / \mathrm{T}$ & $\mathrm{C} / \mathrm{C}+\mathrm{C} / \mathrm{T}$ & $\begin{array}{c}\mathrm{p} \\
(\mathrm{CC}+\mathrm{CT} \text { vs. TT) }\end{array}$ \\
\hline $\mathrm{n}$ & 14 & 28 & 13 & 42 & \\
BMI $\left(\mathrm{kg} / \mathrm{m}^{2}\right)$ & $21.9 \pm 0.6$ & $21.1 \pm 0.5$ & $22.3 \pm 0.6$ & $21.3 \pm 0.4$ & 0.4864 \\
Duration (years) & $13.2 \pm 3.3$ & $13.3 \pm 1.7$ & $15.2 \pm 1.9$ & $13.3 \pm 1.6$ & 0.5817 \\
Treatment (Diet/OHA/Insulin) & $1 / 7 / 6$ & $6 / 19 / 3$ & $1 / 9 / 3$ & $7 / 26 / 9$ & 0.7241 \\
Family History (+/-) & $6 / 8$ & $19 / 9$ & $6 / 7$ & $25 / 17$ & 0.3956 \\
FPG (mg/dl) & $115.4 \pm 6.0$ & $118.1 \pm 3.2$ & $121.2 \pm 4.8$ & $117.2 \pm 2.9$ & 0.3848 \\
HbA $(\%)$ & $8.9 \pm 0.4$ & $9.1 \pm 0.5$ & $8.9 \pm 0.4$ & $9.0 \pm 0.4$ & 0.5497 \\
F-IRI $(\mu \mathrm{H} / \mathrm{ml})$ & $5.4 \pm 1.1$ & $5.6 \pm 0.8$ & $5.6 \pm 0.8$ & $5.5 \pm 0.6$ & 0.0886 \\
HOMA-IR & $1.6 \pm 0.4$ & $1.7 \pm 0.3$ & $1.6 \pm 0.2$ & $1.6 \pm 0.2$ & 0.9990 \\
I.I. & $0.18 \pm 0.03$ & $0.14 \pm 0.02$ & $0.07 \pm 0.02$ & $0.15 \pm 0.02$ & 0.0680 \\
u-CPR ( $\mu$ g/day) & $79.5 \pm 11.3$ & $60.4 \pm 8.1(24)$ & $48.9 \pm 8.0$ & $67.5 \pm 6.7$ & 0.3781 \\
$\Delta$ CPR & $2.1 \pm 0.3$ & $2.0 \pm 0.2(26)$ & $1.6 \pm 0.3$ & $2.0 \pm 0.2$ & 0.5755 \\
AUC-insulin & $56.2 \pm 6.6$ & $46.6 \pm 8.2$ & $35.2 \pm 5.6$ & $49.8 \pm 6.0$ & 0.0272 \\
\hline
\end{tabular}

Data are $\mathrm{n}$ or mean \pm SEM. HOMA-IR $=\mathrm{FPG}(\mathrm{mg} / \mathrm{dl}) \times \mathrm{F}-\mathrm{IRI}(\mu \mathrm{U} / \mathrm{ml}) / 405$.

Obese: BMI $\geq 25 \mathrm{~kg} / \mathrm{m}^{2}$, non-obese: BMI $<25 \mathrm{~kg} / \mathrm{m}^{2}$, I.I.: insulinogenic index. AUC: area under the curve. Family History: presence of type 2 diabetes among their third-degree relatives. Data of FPG, F-IRI, and HOMA-IR at the time of 75 g-OGTT are shown. Numbers of available data are shown in each parenthesis.

insulinogenic index (I.I.), urinary C-peptide level, $\triangle \mathrm{CPR}$ in the glucagon test, and area under the plasma insulin curve (AUC-insulin) during the OGTT in relation to the genotypes of rs 1884614 (data not shown). However, among non-obese subjects (BMI $<25 \mathrm{~kg}$ / $\mathrm{m}^{2}$ ), we found a significant association between rs 1884614 and AUC-insulin (Table 5). The T/T genotype of rs1884614 was significantly associated with a smaller AUC-insulin $(35.2 \pm 5.6$ for T/T vs. $49.8 \pm 6.0$ for $\mathrm{C} / \mathrm{C}+\mathrm{C} / \mathrm{T}, \mathrm{p}=0.0272$ ) after adjustment for age and sex. In contrast, the association was not found in obese patients (BMI $\geq 25 \mathrm{~kg} / \mathrm{m}^{2}$ ). Although not significant, there was also a tendency of association between the T/T genotype of rs1884614 and the lower I.I. in non-obese diabetic patients $(\mathrm{p}=0.068$; adjusted for age and sex). 


\section{Discussion}

Recent genetic studies have shown that SNPs such as rs 1884614 in the $\mathrm{P} 2$ promoter region of the HNF- $4 \alpha$ gene display a significant association with type 2 diabetes in several populations [8-13]. However, the influence of variations in the P2 region of the HNF- $4 \alpha$ gene remains controversial with respect to the Japanese population. One study has shown that a haplotype consisting of rs1884614 (T) and $\mathrm{rs} 2144908(\mathrm{G})$ is significantly associated with type 2 diabetes in Japanese [14]. In contrast, this haplotype was not detected among either diabetic or non-diabetic Japanese subjects in another study [15]. In the present study, we also did not find this haplotype in our cohort and failed to demonstrate any significant association of these SNPs with type 2 diabetes. Further studies in larger cohorts will be required to fully define the influence of these SNPs of the HNF- $4 \alpha$ gene on the development of type 2 diabetes in the Japanese population.

Impaired acute secretion of insulin by pancreatic $\beta$ cells is a characteristic of HNF- $4 \alpha$ deficiency in both humans and mice [4-7]. One study from Finland reported that non-diabetic subjects with the risk of $\mathrm{A}$ allele for rs2144908 (in nearly perfect linkage disequilibrium with the $\mathrm{T}$ allele for rs 1884614) had a weaker plasma insulin response to glucose [8]. In addition, the T/T genotype of rs 1884614 is significantly associated with a lower insulin secretion index in Thais [21]. Therefore, we examined the relation of rs 1884614 to various clinical characteristics of Japanese diabetic subjects. Consistent with previous observations, we also detected a significant association between the T/T genotype of rs1884614 and a smaller AUC-insulin during the OGTT in non-obese diabetic patients. These associations across several studies strongly suggest that the risk allele of rs 1884614 (or rs2144908) contributes to insulin response. When we adjusted AUC-insulin data for duration of diabetes, in addition to age and sex, the difference between $\mathrm{T} / \mathrm{T}$ and $\mathrm{C} /$ $\mathrm{C}+\mathrm{C} / \mathrm{T}$ genotypes disappeared $(\mathrm{p}=0.836)$. Since it is difficult to determine the precise date of onset of type
2 diabetes, the lack of association after adjustment for duration of diabetes may not rule out the association between rs 1884614 and insulin secretion. The region between $-27 \mathrm{~kb}$ upstream and $17 \mathrm{~kb}$ downstream of the P2 promoter is a single large block that shows strong linkage disequilibrium in Japanese individuals, and rs1884614 is located in this block [14]. One possibility is that rs 1884614 may directly influence HNF$4 \alpha$ gene expression and insulin secretion, but the observed association may also reflect linkage disequilibrium with an unknown causative variation. The effects of these SNPs on P2 promoter activity of the HNF-4 $\alpha$ gene remain unclear at this stage. Further investigation is required to elucidate the functional importance of these SNPs.

Interestingly, an effect of the $\mathrm{T} / \mathrm{T}$ genotype on AUC-insulin was not detected in obese (BMI $\geq 25 \mathrm{~kg} /$ $\mathrm{m}^{2}$ ) diabetic patients. We have no good explanation as to why the association was only observed in non-obese patients. One cannot exclude an interaction between genes or environmental factors involved in both obesity and rs1884614 to cause susceptibility to defective insulin secretion. Obesity is generally associated with hyperinsulinemia. The detrimental effect of this SNP might have been obscure in obese patients with hyperinsulinemia.

In conclusion, there was no association between two SNPs of HNF-4 $\alpha$ (rs1884614 and rs2144908) and the occurrence of type 2 diabetes in Japanese subjects. However, SNP rs1884614 in the P2 promoter region of the HNF- $4 \alpha$ gene may influence insulin secretion in non-obese diabetic patients.

\section{Acknowledgements}

We thank J. Kozawa, T. Nammo, Y. Okauchi, I. Hayashi, K. Sayama, A. Miura, S. Umemura, Y. Kuroda, S. Nakata, and S. Tamba for their valuable help with this study. This study was supported by grants from the Japanese Ministry of Science, Education, Sports, Culture and Technology.

\section{References}

1. Yamagata K (2003) Regulation of pancreatic beta-cell function by the HNF transcription network: lessons from maturity-onset diabetes of the young (MODY).
Endocr J 50: 491-499.

2. Nammo $T$, Yamagata $K$, Tanaka $T$, Kodama $T$, Sladek FM, Fukui K, Katsube F, Sato Y, Miyagawa J, 
Shimomura I (2008) Expression of HNF-4 $\alpha$ (MODY1), HNF-1 $\beta$ (MODY5), and HNF-1 $\alpha$ (MODY3) proteins in the developing mouse pancreas. Gene Expression Patterns 8: 96-106.

3. Yamagata K, Furuta H, Oda N, Kaisaki PJ, Menzel S, Cox NJ, Fajans SS, Signorini S, Stoffel M, Bell GI (1996) Mutations in the hepatocyte nuclear factor-4 alpha gene in maturity-onset diabetes of the young (MODY1). Nature 384(6608): 407-408.

4. Byrne MM, Sturis J, Fajans SS, Ortiz FJ, Stoltz A, Stoffel M, Smith MJ, Bell GI, Halter JB, Polonsky KS (1995) Altered insulin secretory responses to glucose in subjects with a mutation in the MODY1 gene on chromosome 20. Diabetes 44(6): 699-704.

5. Herman WH, Fajans SS, Smith MJ, Polonsky KS, Bell GI, Halter JB (1997) Diminished insulin and glucagon secretory responses to arginine in nondiabetic subjects with a mutation in the hepatocyte nuclear factor-4 alpha/MODY1 gene. Diabetes 46(11): 1749-1754.

6. Miura A, Yamagata K, Kakei M, Hatakeyama H, Takahashi N, Fukui K, Nammo T, Yoneda K, Inoue Y, Sladek FM, Magnuson MA, Kasai H, Miyagawa J, Gonzalez FJ, Shimomura I (2006) Hepatocyte nuclear factor-4 alpha is essential for glucose-stimulated insulin secretion by pancreatic beta-cells. J Biol Chem 24; 281(8): 5246-5257.

7. Gupta RK, Vatamaniuk MZ, Lee CS, Flaschen RC, Fulmer JT, Matschinsky FM, Duncan SA, Kaestner KH (2005) The MODY1 gene HNF-4 alpha regulates selected genes involved in insulin secretion. J Clin Invest 115(4): 1006-1015.

8. Silander K, Mohlke KL, Scott LJ, Peck EC, Hollstein P, Skol AD, Jackson AU, Deloukas P, Hunt S, Stavrides G, Chines PS, Erdos MR, Narisu N, Conneely KN, Li C, Fingerlin TE, Dhanjal SK, Valle TT, Bergman RN, Tuomilehto J, Watanabe RM, Boehnke M, Collins FS (2004) Genetic variation near the hepatocyte nuclear factor-4 alpha gene predicts susceptibility to type 2 diabetes. Diabetes 53(4): 1141 1149.

9. Love-Gregory LD, Wasson J, Ma J, Jin CH, Glaser B, Suarez BK, Permutt MA (2004) A common polymorphism in the upstream promoter region of the hepatocyte nuclear factor- 4 alpha gene on chromosome 20q is associated with type 2 diabetes and appears to contribute to the evidence for linkage in an Ashkenazi Jewish population. Diabetes 53(4): 1134-1140.

10. Weedon MN, Owen KR, Shields B, Hitman G, Walker M, McCarthy MI, Love-Gregory LD, Permutt MA, Hattersley AT, Frayling TM (2004) Common variants of the hepatocyte nuclear factor-4 alpha P2 promoter are associated with type 2 diabetes in the U.K. population. Diabetes 53(11): 3002-3006.

11. Damcott CM, Hoppman N, Ott SH, Reinhart LJ, Wang
J, Pollin TI, O'Connell JR, Mitchell BD, Shuldiner AR (2004) Polymorphisms in both promoters of hepatocyte nuclear factor 4-alpha are associated with type 2 diabetes in the Amish. Diabetes 53(12): 3337-3341.

12. Hansen SK, Rose CS, Glümer C, Drivsholm T, BorchJohnsen K, Jørgensen T, Pedersen O, Hansen T (2005) Variation near the hepatocyte nuclear factor (HNF)-4 alpha gene associates with type 2 diabetes in the Danish population. Diabetologia 48: 452-458.

13. Lehman DM, Richardson DK, Jenkinson CP, Hunt KJ, Dyer TD, Leach RJ, Arya R, Abboud HE, Blangero J, Duggirala R, Stern MP (2007) P2 promoter variants of the hepatocyte nuclear factor 4 alpha gene are associated with type 2 diabetes in Mexican Americans. Diabetes 56(2): 513-517.

14. Hara K, Horikoshi M, Kitazato H, Ito C, Noda M, Ohashi J, Froguel P, Tokunaga K, Tobe K, Nagai R, Kadowaki T (2006) Hepatocyte nuclear factor-4 alpha P2 promoter haplotypes are associated with type 2 diabetes in the Japanese population. Diabetes 55(5): 1260-1264.

15. Takeuchi F, Yanai K, Inomata H, Kuzuya N, Kajio H, Honjo S, Takeda N, Kaburagi Y, Yasuda K, Shirasawa S, Sasazuki T, Kato N (2007) Search of type 2 diabetes susceptibility gene on chromosome 20q. Biochem Biophys Res Commun 15; 357(4): 1100-1106.

16. Unger RH, Grundy S (1985) Hyperglycemia as an inducer as well as a consequence of impaired islet cell function and insulin resistance: implications for the management of diabetes. Diabetologia 28: 119-121.

17. Poitout V, Robertson RP (2002) Minireview: Secondary beta-cell failure in type 2 diabetes - a convergence of glucotoxicity and lipotoxicity. Endocrinology 143: 339-342.

18. Robertson RP, Zhang HJ, Pyzdrowski KL, Walseth TF (1992) Preservation of insulin mRNA levels and insulin secretion in HIT cells by avoidance of chronic exposure to high glucose concentrations. J Clin Invest 90: 320-325.

19. Fukuda-Akita E, Okita K, Okauchi Y, Ryo M, Nakamura T, Funahashi T, Iwahashi H, Shimomura I, Miyagawa J, Yamagata K (2008) Impaired early insulin secretion in Japanese type 2 diabetes with metabolic syndrome. Diabetes Res Clin Pract 79(3): 482-489.

20. Pratley RE, Weyer C (2002) The role of impaired early insulin secretion in the pathogenesis of Type II diabetes mellitus. Diabetologia 44: 929-945.

21. Jongjaroenprasert W, Chanprasertyothin S, Kongsuksai A, Bunnag P, Puavilai G, Ongphiphadhanakul B (2007) Association of genetic variations near P2 promoter of the hepatocyte nuclear factor-4 alpha gene and insulin secretion index in Thais. Acta Diabetol 44(4): 227-232. 